\title{
CURRENT
}

Jurnal Kajian Akuntansi dan Bisnis Terkini

https://current.ejournal.unri.ac.id

\section{PENERAPAN SISTEM E-FILLING, KESADARAN PERPAJAKAN, DAN SANKSI PERPAJAKAN PADA KEPATUHAN WAJIB PAJAK ORANG PRIBADI}

\section{Cindy Natalia ${ }^{1}$, Ernie Riswandari ${ }^{2 *}$}

${ }^{1,2}$ Program Studi Akuntansi, Universitas Bunda Mulia, Jakarta

*E-mail : eriswandari@bundamulia.ac.id

\begin{tabular}{l} 
Keywords \\
\hline Compliance, \\
E-Filling, \\
Awareness, \\
Tax Sanctions \\
\hline
\end{tabular}

\section{Article informations}

Received:

2021-06-05

Accepted:

2021-06-26

Available Online:

2021-07-30

\begin{abstract}
This study aims to test the influence of E-Filling implementation, tax awareness, and tax sanctions on the compliance of private taxpayers. The population of this research is a private taxpayer who lives in dki Jakarta area who has an NPWP and has used EFilling. Data in the form of questionnaires disseminated through Google Form and obtained samples used by as many as 100 respondents and processed with Smart PLS 3. The results showed the application of E-Filling system and tax awareness had an effect on the compliance of private taxpayers. While tax sanctions have no effect on the compliance of private taxpayers.
\end{abstract}

\section{PENDAHULUAN}

Dalam menjalankan operasional suatu negara dibutuhkan pendapatan negara. Menurut UU nomor 12 tahun 2018 pemerintah pusat memiliki hak atas berbagai jenis pendapatan yang nantinya sebagai kontribusi untuk kekayaan negara yang meliputi pendapatan atas pendapatan dari sektor pajak, sektor bukan pajak dan hibah. Salah satu dari sekian banyak pendapatan tersebut adalah pendapatan dari penerimaan sektor pajak yang tercatat sebesar Rp920,2 Triliun rupiah hal in diungkapkan oleh menteri keuangan Sri Mulyani. Jumlah penerimaan ini hanya mencakup sebesar 51,5\% dari target pencapaian APBN di tahun 2019. Pajak menduduki posisi pertama dalam sumbangsih pendapatan negara terbesar.

Menurut UU nomor 12 tahun 2018 ayat 3 semua bentuk penerimaan negara seperti penerimaan pajak yang berasal dari dalam negeri dan penerimaan pajak yang didapat dari perdagangan antar negara itu semua merupakan bentuk penerimaan pajak. Semua dari pendapatan tersebut digunakan untuk membangun infrastruktur guna meningkatkan kesejahteraan rakyat. Hal itu memiliki arti yang sama dengan yang tercantum di dalam 
pasal 1 ayat 1 UU No. 6 tahun 1983 yang disempurnakan dalam UU No.29 tahun 2007 yakni pengertian pajak sebuah bentuk partisipasi rakyat yakni orang pribadi yang berstatus wajib pajak dan dapat dipaksakan yang nantinya digunakan untuk memakmurkan.

Berdasarkan data dari DJP jumlah dari WP (Wajib Pajak) yang telah menyampaikan SPT tahunan 2019 sejumlah 13,37 juta Wajib Pajak. Dimana angka tersebut totalnya mencapai 72,9\% dari total Wajib Pajak yang wajib melaporkan Surat Pemberitahuan adalah sejumlah 18,33 juta. Angka yang dicapai ini masih berada di bawah target DJP sebesar 80\%. Apabila lebih dilihat secara mendetail, realisasi kepatuhan formal Wajib Pajak badan hanya mencapai angka 65,28\%. Sementara, kepatuhan Wajib Pajak Orang Pribadi (OP) baik sebagai karyawan maupun pekerjaan lain masing-masing sebesar 73,2\% dan 75,31\%.

Dilansir dari artikel liputan6.com Kementerian Keuangan (Kemenkeu) mencatat bahwa hingga akhir tahun 2019 penerimaan pajak sudah mencapai angka Rp 1.332,1 triliun. Namun, angka ini ternyata belum mencapai target Anggaran Pendapatan dan Belanja Negara (APBN) di tahun 2019 yaitu sebesar Rp 1.577,6 triliun yang bila dipresentasekan maka baru mencapai angka $84 \%$.

DJP juga senantiasa selalu memberikan usaha terbaik agar pelayanan perpajakan yang dirasakan oleh wajib pajak sudah baik dengan melakukan berbagai inovasi dan perubahan pada peraturan-peraturan perpajakan. Untuk itu pihak fiskus atau DJP melakukan berbagai usaha dalam mereformasi administrasi yang ada sekarang hingga terciptalah sistem E-Filling untuk membantu proses pembayaran pajak dalam Lado dan Budiantara (2018).

Dengan terciptanya sistem ini dalam menjalankan kewajiban pajaknya pada sekarang ini wajib pajak sudah sangat mudah. Wajib Pajak dapat melaporkan SPT nya selama 24 jam penuh dalam 7 hari meskipun hari libur. Selain itu, dengan adanya $e$-filling sekarang ini dapat mengurangi biaya yang dulunya timbul akibat penggunaan kertas dalam Simanjuntak dan Siregar (2019).

Tidak tercapainya target penerimaan pajak bukanlah suatu hal yang bisa dibanggakan. Menurut Dharma dan Suardana (2014) dalam Siahaan dan Halimatusyadiah (2018) bila wajib pajak bersungguh-sungguh dalam melaporkan Surat Pemberitahuan serta membayar pajak maka bisa dibilang bahwa hal tersebut sudah menunjukkan kesadaran dari wajib pajak tersebut.

Masyarakat yang memenuhi kewajiban perpajakan sesuai Peraturan Menteri Keuangan (PMK) No.91/PMK.03/2015 akan bebas dari sanksi administratif, sanksi administratif dalam hal ini adalah hukuman yang terjadi sebagai akibat dari terlambat mengajukan SPT atau terlambat melakukan pembayaran pajaknya dari tanggal yang sudah 
menjadi jadwal tetap berdasarkan peraturan. Dengan adanya peraturan ini diharapkan bisa meningkatkan tingkat patuhnya seorang wajib pajak dalam Wijaya (2019).

Berdasarkan latar belakang yang sudah dijabarkan diatas, penulis tertarik untuk meneliti apakah penerapan sistem E-filling, kesadaran perpajakan dan sanksi perpajakan berpengaruh terhadap kepatuhan Wajib Pajak orang pribadi yang akan dilakukan melalui kuesioner yang dibagikan secara Online kepada Wajib Pajak di daerah Jakarta Utara.

\section{PENGEMBANGAN HIPOTESIS}

\section{Penerapan Sistem E-Filling berpengaruh terhadap Kepatuhan Wajib Pajak Orang} Pribadi di DKI Jakarta

Theory of Acceptance Model (TAM) menerangkan bahwa bila seseorang berkeinginan untuk menggunakan sebuah teknologi baru hal itu bisa didasari oleh pengaruh langsung dan tidak langsung untuk persepsi si pengguna akan manfaat yang diberikan dan disediakan oleh sistem tersebut menurut Putra (2019). Bila dikaitkan dengan sistem E-Filling yang merupakan teknologi administrasi yang dikembangkan oleh DJP, maka apabila sistem E-Filling saat ini dirasa oleh pengguna yakni Wajib Pajak memberikan manfaat yang baik bagi efisiensi perpajakan maka tingkat penggunaan sistem ini akan naik yang diharapkan akan sejalan dengan naiknya angka kepatuhan Wajib Pajak. Sejalan dengan Penelitian yang dilakukan oleh Nurlaela (2017) menunjukkan bahwa penerapan sistem E-Filling berpengaruh terhadap kepatuhan Wajib Pajak Orang Pribadi. Luh Putu Santi Krisna Dewi dan Ni Ketut Lely Aryani Merkusiwati (2018) juga mengungkapkan hal yang sama bahwa Sistem E-Filling berpengaruh positif terhadap kepatuhan Pelaporan Wajib Pajak. Menurut penulis Sistem E-Filling yang saat ini sudah semakin memudahkan Wajib Pajak dalam melaporkan semua kewajiban perpajakannya dan sesuai teori TAM maka seharusnya dapat meningkatkan penggunaan sistem ini dan begitu pula dengan angka kepatuhan Wajib Pajak. Oleh karena itu hipotesis yang dapat dibentuk adalah:

$H_{1}$ : Penerapan Sistem E-Filling berpengaruh terhadap kepatuhan Wajib Pajak Orang Pribadi di DKI Jakarta.

Kesadaran Perpajakan Berpengaruh Terhadap Kepatuhan Wajib Pajak Orang Pribadi di DKI Jakarta

Dalam Theory of Planned Behavior (TPB) dikatakan bahwa Individu yang memunculkan sebuah perilaku didasari oleh sebuah niat dimana memang individu ingin atau memiliki niat berprilaku. Sebuah niat untuk berperilaku memiliki 3 faktor penentu, yaitu behavioral beliefs, normative beliefs, dan control beliefs. Behavioral beliefs ini adalah 
faktor yang memiliki niat atau sikap terhadap perilaku yang positif dan negativ. Kesadaran perpajakan pada hakikatnya berasal dari masing-masing pribadi Wajib Pajak, Wajib Pajak sudah seharusnya paham dan tahu mengenai kewajibannya kepada negara dan harus memenuhi kewajiban tersebut. Bila Wajib Pajak sadar dan memenuhi kewajiban perpajakannya kepada negara maka ini adalah tindakan yang positif namun, bila wajib pajak memilih untuk menghindari pajak atau bahkan tidak mau memenuhi kewajiban perpajakannya jelas ini adalah tindakan atau perilaku yang negatif. Penelitian yang dilakukan oleh Dewi dan Merkusiwati (2018) mengungkapkan bahwa kesadaran perpajakan berpengaruh positif terhadap kepatuhan Wajib Pajak. Siahaan dan Halimatusyadiah (2018) juga mengungkapkan hal serupa yakni Kesadaran Perpajakan berpengaruh terhadap Kepatuhan Wajib Pajak.

Menurut penulis tidak dapat dipungkiri bahwa sifat memaksa yang dimiliki pajak tidak sepenuhnya dapat diandalkan untuk memenuhi target penerimaan pajak sepenuhnya, diperlukan juga kesadaran dari masing-masing wajib pajak agar tercapainya penerimaan pajak yang maksimal sesuai terget. Oleh karena itu hipotesis yang dapat dibentuk adalah:

\section{H2: Kesadaran Perpajakan berpengaruh terhadap Kepatuhan Wajib Pajak Orang Pribadi di DKI Jakarta.}

\section{Sanksi Perpajakan Berpengaruh Terhadap Kepatuhan Wajib Pajak Orang Pribadi di DKI} Jakarta

Dalam Theory of Planned Behavior (TPB) dikatakan bahwa Individu yang memunculkan sebuah perilaku didasari oleh sebuah niat dimana memang individu ingin atau memiliki niat berprilaku. Sebuah niat untuk berperilaku memiliki 3 faktor penentu, yaitu behavioral beliefs, normative beliefs, dan control beliefs. Normative beliefs ini faktor yang menghasilkan sebuah tekanan sosial yang dipersepsikan dan Control beliefs adalah faktor yang menghasilkan sebuah kontrol perilaku yang dipersepsikan. Sanksi perpajakan yang berlaku di Indonesia dalam bentuk Sanksi Pidana dan Administratif adalah sebuah bentuk tekanan dan kontrol secara tidak langsung yang diberikan oleh pemerintah kepada wajib pajak. Wajib pajak akan merasa mendapat tekanan apabila tidak melakukan kewajiban perpajakannya karena ada sanksi yang harus dihadapi kemudian hari, begitu pula pemerintah melalui sanksi yang ada secara tidak langsung mengontrol wajib pajak agar selalu patuh supaya terhindar dari sanksi yang berat. Bila sanksi yang ada diterapkan dengan sebaikbaiknya oleh pemerintah maka tekanan dan kontrol yang diberikan kepada wajib pajak akan dirasa semakin intens. Penelitian yang dilakukan Dewi dan Merkusiwati (2018) mengungkapkan bahwa sanksi perpajakan berpengaruh positif terhadap kepatuhan Wajib 
Pajak. Siahaan dan Halimatusyadiah (2018) juga mengungkapkan hal serupa yakni sanksi perpajakan berpengaruh terhadap Kepatuhan Wajib Pajak.

Namun, hal ini tidak sejalan dengan penelitian yang dilakukan oleh Ermawati dan Afifi yang menyebutkan bahwa sanksi perpajakan tidak berpengaruh signifikan terhadap Kepatuhan wajib pajak. Menurut penulis sanksi perpajakan cukup memiliki kekuatan untuk membuat wajib pajak merasa takut dan akhirnya patuh membayar pajak agar terhindar dari sanksi administrasi maupun pidana yang cukup serius berdasarkan undang-undang. Oleh karena itu hipotesis yang dapat dibentuk adalah:

\section{H3: Sanksi Perpajakan berpengaruh terhadap Kepatuhan Wajib Pajak Orang Pribadi di DKI Jakarta.}

\section{METODE PENELITIAN}

Penelitian ini menggunakan pendekatan kuantitatif dengan jenis data primer. Teknik pengambilan data melalui penyebaran Kuesioner secara online yang dilakukan melalui Google form. Pengolahan data dilakukan dengan aplikasi Smart PLS 3 Partial Least Square (PLS) adalah salah satu metode varian yang didesain untuk menyelesaikan regresi berganda ketika terjadi permasalahan spesifik seperti ukuran data sampel yang kecil dan ada data yang hilang menurut Prathama dan Sahetapy (2019) dimana uji statistic yang dilakukan nantinya dapat menguji hipotesis-hipotesis dan memberikan jawaban dari rumusan masalah. Penulis memilih wajib pajak orang pribadi yang ada diwilayah DKI Jakarta sebagai populasi. Penulis memilih metode Snowball Sampling yaitu teknik sampel dimana sebenarnya jumlah responden kecil namun, dari responden inilah kuesioner akan disebar sehingga menjadi besar sebagai teknik pengambilan sampel dalam penelitian. Hal ini cocok untuk dilakukan dalam penyebaran kuesioner secara online. Jumlah sampel untuk metode analisis data multivariat atau regresi berganda dengan variabel bebas lebih dari satu adalah 10 kali banyak variabel menurut Hair et al, 2010 dalam Solimun, Armanu dan Rinaldo Fernandes (2018).

Berikut adalah definisi dan pengukuran variabel yang digunakan penulis:

\section{Kepatuhan Wajib Pajak}

Merupakan sikap dimana wajib pajak patuh terhadap peraturan mengenai pajak baik individu maupun badan sehingga bila ada ketidakpatuhan maka akan ada upaya untuk menghindari pajak menurut Sunarto (2020) indikator: 1) Sebagai wajib pajak maka sudah seharusnya melakukan pendaftaran untuk memperoleh NPWP, 2) Patuh dalam Menyetorkan SPT, 3) Patuh dalam hal menghitung pembayaran Pajak yang terutang, 4) Patuh untuk 
melunasi tunggakan.

\section{Penerapan Sistem E-Filling}

Merupakan salah satu bentuk upaya DJP dalam memodernkan atau memodernisasi sistem administrasi pajak yang ada melalui perkembangan teknologi dengan pelaporan secara online menurut (Sunarto 2020) indikator: 1) Pengetahuan Internet, 2) Sistem Mudah digunakan, 3) Keamanan yang komprehensif.

\section{Kesadaran Perpajakan}

Memiliki kesadaran pajak yang tinggi sejak dini dalam diri masing-masing wajib pajak sangat diperlukan baik itu mengenai peraturan maupun perhitungan sehingga nantinya wajib pajak tidak perlu dipaksakan lagi pembayaran pajaknya menurut Khuzaimah dan Hermawan (2018) indikator: 1) Pajak bentuk partisipasi dalam menunjang pembangunan negara, 2) Penundaan pembayaran pajak sangat merugikan negara, 3) Pajak ditetapkan undang-undang, 5) Tidak membayar pajak yang sesuai merugikan Negara

\section{Sanksi Perpajakan}

Berupa bentuk tindakan yang dikenakan0apabila wajib pajak tidak melaksanakan kewajiban mereka tepat waktu bisa berupa sanksi administrasi maupun pidana menurut (Sunarto 2020) indikator: 1) Tegas dan Jelas merupakan unsur utama yang harus ada dalam Sanksi Perpajakan yang dijalankan, 2) Dalam menjalankan sanksi perpajakan aparat tidak boleh kompromi dalam hal apapun, 3) Dalam memberikan sanksi pihak fiskus harus bersikap seimbang terhadap semua pihak, 4) Sanksi yang dibuat harus terdapat unsur yang membuat jera wajib pajak yang melanggar.

\section{HASIL PENELITIAN DAN PEMBAHASAN}

Kuesioner yang disebar oleh peneliti terdiri dari 30 pertanyaan yang terbagi dalam: a) 8 pernyataan untuk mengukur Kepatuhan Wajib Pajak (Y), b) 6 pernyataan untuk mengukur Penerapan Sistem E-Filling (X1), c) 8 pernyataan untuk mengukur Kesadaran Perpajakan (X2), d) 8 pernyataan untuk mengukur Sanksi Perpajakan (X3).

Namun, karena terdapat pernyataan yang dinilai tidak valid melalui uji yang dilakukan maka dihapus sehingga hanya ada 7 pernyataan yang digunakan. Pernyataan yang digunakan mengambil referensi dari Indikator yang ada di jurnal sesuai dengan tabel Definisi Operasional yang dikembangkan dengan satu indikator memiliki dua pernyataan.

Penelitian ini menggunakan skala likert dengan nilai 1 (tidak setuju), 2 (kurang setuju), 3 (Ragu-ragu), 4 (setuju), 5 (sangat setuju). 
Responden yang didapat oleh penulis sebesar 119 respons namun, tidak bisa semuanya digunakan karena ada yang tidak sesuai kriteria seperti yang dijelaskan ditabel dibawah.

\section{Tabel 1}

\section{Data Jumlah Kuesioner}

\begin{tabular}{lcc}
\hline \multicolumn{1}{c}{ Kuesioner yang diperoleh } & Jumlah & Persentase \\
\hline Kuesioner yang tidak memenuhi kriteria, terdiri dari: & $\mathbf{1 1 9}$ & $\mathbf{1 0 0 \%}$ \\
1. Tidak memiliki NPWP & & $5,04 \%$ \\
2. Tidak pernah menggunakan E-Filling & 6 & $5,89 \%$ \\
3. Berdomisili diluar DKI Jakarta & 7 & $4,20 \%$ \\
4. Data ganda & 5 & $0,84 \%$ \\
\hline Kuesioner yang dapat digunakan & 1 & $84,03 \%$ \\
\hline
\end{tabular}

Sumber: Data primer $n=100(2021)$

\section{Hasil Uji Validitas}

Hasil uji validitas dengan menggunakan faktor loading dapat dilihat pada tabel 2.

\section{Tabel 2}

Nilai Outer Loading

\begin{tabular}{|c|c|c|c|c|}
\hline & $\begin{array}{c}\text { Penerapan } \\
\text { E-Filling }\end{array}$ & $\begin{array}{l}\text { Kesadaran } \\
\text { Perpajakan }\end{array}$ & Sanksi Perpajakan & $\begin{array}{c}\text { Kepatuhan } \\
\text { Wajib Pajak }\end{array}$ \\
\hline E1 & 0.790 & & & \\
\hline $\mathrm{E} 2$ & 0.807 & & & \\
\hline E3 & 0.849 & & & \\
\hline E4 & 0.571 & & & \\
\hline E5 & 0.611 & & & \\
\hline E6 & 0.684 & & & \\
\hline KS1 & & 0.771 & & \\
\hline KS2 & & 0.772 & & \\
\hline KS3 & & 0.785 & & \\
\hline KS4 & & 0.757 & & \\
\hline KS5 & & 0.520 & & \\
\hline KS6 & & 0.630 & & \\
\hline KS7 & & 0.827 & & \\
\hline KS8 & & 0.781 & & \\
\hline $\mathrm{S} 1$ & & & 0.805 & \\
\hline $\mathrm{S} 2$ & & & 0.779 & \\
\hline S3 & & & 0.780 & \\
\hline $\mathrm{S} 4$ & & & 0.765 & \\
\hline S5 & & & 0.864 & \\
\hline S6 & & & 0.828 & \\
\hline S7 & & & 0.760 & \\
\hline S8 & & & 0.641 & \\
\hline $\mathrm{K} 1$ & & & & 0.666 \\
\hline $\mathrm{K} 2$ & & & & 0.703 \\
\hline K3 & & & & 0.586 \\
\hline K4 & & & & 0.780 \\
\hline K5 & & & & 0.792 \\
\hline K6 & & & & 0.847 \\
\hline K7 & & & & 0.545 \\
\hline
\end{tabular}

Sumber: Output SmartPLS 3, Data primer $n=100$ (2021)

Berdasarkan tabel 2 maka dapat dilihat bahwa Indikator yang digunakan dalam 
penelitian ini dikatakan valid apabila nilai Loading Factor diatas atau lebih dari 0,50. Selain itu untuk mengukur valid atau tidak nya juga bisa dilihat dari nilai Cross Loading (Tabel 3)

Tabel 3

Nilai Cross Loading

\begin{tabular}{ccccc}
\hline & $\begin{array}{c}\text { Penerapan } \boldsymbol{E} \text { - } \\
\text { Filling }\end{array}$ & $\begin{array}{c}\text { Kesadaran } \\
\text { Perpajakan }\end{array}$ & $\begin{array}{c}\text { Sanksi } \\
\text { Perpajakan }\end{array}$ & $\begin{array}{c}\text { Kepatuhan } \\
\text { Wajib Pajak }\end{array}$ \\
\hline E1 & X1 & X2 & X3 & X4 \\
E2 & 0.790 & 0.205 & 0.269 & 0.298 \\
E3 & 0.807 & 0.420 & 0.405 & 0.283 \\
E4 & 0.849 & 0.296 & 0.374 & 0.418 \\
E5 & 0.571 & 0.262 & 0.329 & 0.418 \\
E6 & 0.611 & 0.368 & 0.417 & 0.220 \\
KS1 & 0.684 & 0.428 & 0.515 & 0.298 \\
KS2 & 0.296 & 0.771 & 0.245 & 0.290 \\
KS3 & 0.332 & 0.772 & 0.381 & 0.380 \\
KS4 & 0.247 & 0.785 & 0.279 & 0.224 \\
KS5 & 0.287 & 0.757 & 0.236 & 0.292 \\
KS6 & 0.187 & 0.520 & 0.285 & 0.230 \\
KS7 & 0.364 & 0.630 & 0.370 & 0.357 \\
KS8 & 0.400 & 0.827 & 0.313 & 0.347 \\
S1 & 0.408 & 0.781 & 0.521 & 0.382 \\
S2 & 0.267 & 0.365 & 0.805 & 0.351 \\
S3 & 0.359 & 0.294 & 0.779 & 0.309 \\
S4 & 0.430 & 0.273 & 0.780 & 0.268 \\
S5 & 0.377 & 0.298 & 0.765 & 0.213 \\
S6 & 0.489 & 0.470 & 0.864 & 0.292 \\
S7 & 0.568 & 0.482 & 0.828 & 0.382 \\
S8 & 0.286 & 0.257 & 0.760 & 0.252 \\
K1 & 0.454 & 0.390 & 0.641 & 0.246 \\
K2 & 0.316 & 0.317 & 0.232 & 0.666 \\
K3 & 0.298 & 0.298 & 0.395 & 0.703 \\
K4 & 0.332 & 0.096 & 0.173 & 0.586 \\
K5 & 0.372 & 0.414 & 0.373 & 0.780 \\
K6 & 0.249 & 0.294 & 0.210 & 0.792 \\
K7 & 0.313 & 0.328 & 0.323 & 0.847 \\
Sumbr: & 0.102 & 0.369 & 0.067 & 0.545 \\
\hline
\end{tabular}

Sumber: Output SmartPLS 3, Data primer $n=100$ (2021)

Berdasarkan pada tabel diatas, dapat dilihat bahwa nilai Cross Loading masingmasing Indikator pembentuk variabel adalah lebih besar nilainya dibandingkan indikator terhadap variabel lainnya. Maka dapat dikatakan semua indikator dalam penelitian ini valid.

\section{Hasil Uji Reabilitas}


Selanjutnya hasil uji reliabilatas dapat dilihat pada tabel 4.

Tabel 4

Nilai Cronbach's Alpha, Composite Reability Dan Ave

\begin{tabular}{|c|c|c|c|}
\hline & Cronbach's Alpha & Composite Reability & $\begin{array}{c}\text { Average Variance } \\
\text { Extracted }\end{array}$ \\
\hline Penerapan sistem E-Filling & 0.820 & 0.868 & 0.527 \\
\hline Kesadaran Perpajakan & 0.876 & 0.903 & 0.542 \\
\hline Sanksi Perpajakan & 0.908 & 0.925 & 0.609 \\
\hline Kepatuhan Perpajakan & 0.832 & 0.875 & 0.504 \\
\hline
\end{tabular}

Sumber: Output SmartPLS 3, Data primer $n=100$ (2021)

Berdasarkan pada tabel diatas, dapat dilihat bahwa angka Cronbach's Alpha yang dihasilkan oleh semua variabel nilainya lebih besar daripada 0.70 sehingga dapat ditarik kesimpulan bahwa semua variabel dalam penelitian ini dapat dikatakan Reliabel.

Dapat dilihat juga pada nilai Composite Reability yang dihasilkan oleh seluruh variabel dalam penelitian nilainya diatas atau lebih besar dari 0.70 dan nilai AVE yang dihasilkan oleh semua variabel nilainya lebih besar dari 0.50 sehingga dapat ditarik sebuah kesimpulan bahwa semua variabel penelitian ini telah Valid dan Reliabel.

\section{Hasil Uji Inner Model}

Tabel 5

Nilai R-Square

\begin{tabular}{lc}
\hline Nilai R-Square Variabel & R-Square \\
\hline Y(Kepatuhan Wajib Pajak) & 0.263 \\
\hline
\end{tabular}

Sumber: Output SmartPLS 3, Data primer n=100 (2021)

Nilai yang diperoleh R-Square untuk variabel Kepatuhan Wajib Pajak adalah sebesar 0.263 artinya persentase yang dapat dijelaskan oleh variabel Penerapan Sistem E-Filling, Kesadaran Perpajakan, dan Sanksi Perpajakan terhadap Kepatuhan Wajib Pajak adalah sebesar $26.3 \%$ dan sisanya sebesar $73.7 \%$ dijelaskan oleh variabel lain atau faktor lain diluar penelitian ini.

\section{Hasil Uji Hipotesis}

Tabel 6

Nilai T-Statistics

\begin{tabular}{lccc}
\hline \multicolumn{1}{c}{ Pengaruh } & $\begin{array}{c}\text { Original } \\
\text { Sample }\end{array}$ & T-Statistics & Keterangan \\
\hline Penerapan E-Filling => Kepatuhan Wajib Pajak & 0.209 & 2.007 & Diterima \\
Kesadaran Perpajakan => Kepatuhan Wajib Pajak & 0.281 & 2.439 & Diterima \\
Sanksi Perpajakan => Kepatuhan Wajib Pajak & 0.143 & 1.262 & Ditolak \\
\hline
\end{tabular}

Sumber: Output SmartPLS 3, Data primer $n=100$ (2021) 
Berdasarkan tabel diatas maka dapat disimpulkan beberapa jawaban yaitu:

\section{Penerapan Sistem E-Filling dan Kepatuhan Wajib Pajak (H1)}

Dapat disimpulkan bahwa pengaruh Penerapan Sistem E-Filling terhadap Kepatuhan Wajib Pajak berpengaruh signifikan karena nilai T-Statistics lebih besar dari 1.96 yakni 2.054 > 1.96 dan memiliki arah positif karena nilai original sample 0.209 bernilai positif yang artinya bahwa semakin baik Penerapan Sistem E-Filling oleh pihak pemerintah maka angka Kepatuhan Wajib Pajak juga akan semakin naik, berdasarkan hasil ini maka $\mathrm{H}_{1}$ diterima. Hal ini juga sejalan bila dikaitkan dengan teori TAM dimana bila penerapan sistem ini semakin baik maka bisa memberikan pengaruh untuk wajib pajak agar semakin ingin menggunakan program E-Filling ini yang nantinya berpengaruh untuk menaikkan angka kepatuhan pelaporan oleh wajib pajak. Mayoritas responden yang terlibat juga berada dalam usia produktif yang akrab dengan teknologi yang mana dianggap sudah tidak asing lagi dalam menggunakan teknologi sistem E-Filling sehingga mendukung hasil uji pada variabel ini.

\section{Kesadaran Perpajakan dan Kepatuhan Wajib Pajak (H2)}

Dapat disimpulkan bahwa pengaruh Kesadaran Perpajakan berpengaruh Signifikan terhadap Kepatuhan Wajib Pajak karena nilai T-Statistics lebih besar dari 1.96 yakni $2.478>$ 1.96 yang artinya semakin Wajib Pajak memiliki kesadaran sendiri untuk membayar pajaknya maka angka Kepatuhan wajib Pajak juga akan semakin naik, dan memiliki arah hubungan positif karena nilai original sample 0.281 yang bernilai positif berdasarkan hasil ini maka $\mathrm{H}_{2}$ diterima. Hal ini sejalan dengan teori behavioral beliefs dimana hal ini didasarkan oleh faktor yang memiliki niat atau sikap terhadap perilaku yang positif dan negativ. Kesadaran merupakan niat individu sendiri untuk memilih berperilaku yang mana baik itu positif maupun negatif, bila Wajib Pajak sadar akan kewajiban perpajakannya maka hal positif yang akan terjadi yakni kewajiban perpajakan yang dilunasinya.

\section{Sanksi Perpajakan dan Kepatuhan Wajib Pajak (H3)}

Dapat disimpulkan bahwa Pengaruh Sanksi Perpajakan tidak berpengaruh secara Signifikan terhadap Kepatuhan Wajib Pajak karena nilai T-Statistics lebih kecil dari 1.96 yakni $1.316<1.96$ dan memiliki arah hubungan positif karena nilai original sample 0.143 yang bernilai positif. Sanksi pajak merupakan konsekuensi yang diberikan oleh pihak berwenang kepada wajib pajak yang melanggar aturan.

Dari hasil survey yang telah dilakukan oleh penulis melalui kuesioner yang disebar terdapat 34 responden yang merasa ragu-ragu mengenai pernyataan bahwa sanksi yang diberikan telah tegas juga sebanyak 33 responden merasa ragu mengenai pernyataan bahwa 
pengenaan sanksi pajak sudah merata dan sebanyak 27 responden merasa ragu terhadap pernyataan bahwa sanksi pajak yang berlaku tidak mengenal kompromi. Ini didapat dari total 100 responden. Fenomena inilah yang membuat wajib pajak merasa bahwa sanksi perpajakan yang berlaku belum sepenuhnya ditegakkan oleh pemerintah, berdasarkan hasil ini maka $\mathrm{H}_{3}$ ditolak. Bila dikaitkan dengan teori normative beliefs ini merupakan faktor yang menghasilkan sebuah tekanan sosial yang dipersepsikan jadi, sanksi perpajakan yang berlaku merupakan sebuah tekanan yang membuat wajib pajak akan merasa wajib untuk menunaikan kewajibannya namun, bila tekanan tersebut tidak lagi kuat atau intens maka kepercayaan mereka akan berkurang untuk bersikap taat.

Hasil penelitian yang didapat juga sejalan dengan penelitian yang dilakukan oleh Ermawati dan Zaenal (2018) bahwa sanksi perpajakan tidak berpengaruh signifikan terhadap kepatuhan wajib pajak. Sehingga dapat dinyatakan bahwa Penerapan Sistem EFilling (X1) dan Kesadaran Perpajakan (X2) berpengaruh signifikan terhadap kepatuhan wajib pajak (Y) sedangkan Sanksi Perpajakan (X3) tidak berpengaruh secara Signifikan terhadap Kepatuhan wajib pajak. Yang artinya H1 dan H2 diterima sedangkan H3 ditolak.

\section{SIMPULAN}

Kesimpulan penelitian ini adalah penerapan sistem E-Filling, kesadaran perpajakan berpengaruh positif terhadap kepatuhan wajib pajak orang pribadi sedangkan sanksi perpajakan tidak berpengaruh terhadap kepatuhan wajib pajak orang pribadi. Keterbatasan dalam penelitian ini adalah kurangnya jumlah responden yang didapat mengingat area populasi penelitian yang luas dan kuesioner yang disebar secara online bisa menimbulkan bias serta masalah verifikasi data terkait apakah responden benar-benar memiliki NPWP adalah hal yang sulit karena tidak semua orang ingin memberikan informasi pribadi berupa NPWP. Saran untuk penelitian selanjutnya agar dapat melakukan penelitian secara langsung di KPP terdekat, dan dapat menambah variabel baru.

\section{REFERENSI}

Dewi, L. P. S. K. (2018). Pengaruh Kesadaran Wajib Pajak, Sanksi Perpajakan, E-Filling, dan tax Amnesty terhadap Kepatuhan Pelaporan Wajib Pajak. E-Jurnal Akuntansi Universitas Udayana Vol.22.2, 2018: 1626-1655.

Ermawati, N., \& Zaenal, A. (2018) Pengaruh Pengetahuan Perpajakan dan Sanksi Perpajakan terhadap Kepatuhan Wajib Pajak dengan Religiusitas sebagai Variabel Pemoderasi .Prosiding SENDI .

Khuzaimah, N., \& Sigit, H. (2018) Pengaruh Tingkat Pemahaman Wajib Pajak, Kesadaran Wajib pajak, dan Sanksi Pajak terhadap kepatuhan Wajib Pajak. Journal of Islamic 
Accounting and Tax, : 37-48.

Lado, Y. O., \& M Budiantara. (2018) Pengaruh Penerapan Sistem E-Filling terhadap Kepatuhan Wajib Pajak Orang Pribadi Pegawai Negeri Sipil.

Nurlaela, L. (2017) Pengaruh Penerapan E-Filling terhadap Kepatuhan Wajib Pajak di KPP Pratama garut. Jurnal Wahana Akuntansi Vol.2 No.2,: 001-008.

Pajak, Tim Edukasi Perpajakan Direktorat Jenderal. (2016) Materi Terbuka Kesadaran Pajak untuk Perguruan Tinggi. Jakarta: Direktorat Jenderal Pajak Kementrian Keuangan Republik Indonesia.

Penerimaan Pajak 2019 Hanya Capai 84,4 Persen dari Target. Januari 7, 2020. https://www.liputan6.com/bisnis/read/4150039/penerimaan-pajak-2019-hanya-capai844-persen-dari-target (accessed Maret 25, 2020).

Prathama, F., \& Wilma, L. S. (2019) Pengaruh Kemudahan Penggunaan Aplikasi dan Kepercayaan konsumen terhadap Minat beli ulang Konsumen E-Commerce Lazada. AGORA vol.7 no.1, 2019

Putra, I.P. O. M. (2019) Pengaruh Kesiapan Teknologi, Sumber Daya Manusia, Kerumitan, Keamanan Dan Kerahasiaan Terhadap Minat Dalam Menggunakan E-Filing. E-jurnal akuntansi , 2019: 225-241.

Siahaan, S., \& Halimatusyadiah. (2018) Pengaruh Kesadaran Perpajakan, Sosialisasi Perpajakan, Pelayanan Fiskus, dan Sanksi Perpajakan terhadap Kepatuhan Wajib Pajak Orang Pribadi . Jurnal Akuntansi Vol.8 No.1, 2018: 1-13.

Simanjuntak, M., \& Yentina,S.(2019) Pengaruh Persepsi dan Perilaku Wajib Pajak atas penerapan E-Filling terhadap Kepatuhan Wajib Pajak Pribadi yang terdaftar di KPP Batam Selatan.Jurnal Dimensi Vol.8 No.2, 2019: 329-341.

Solimun, A., \& Adi, A.R F. (2018) Metodologi Penelitian Kuantitaif Perspektif Sistem (Mengungkap Novelty dan Memenuhi Validitas Penelitian). Malang: UB Press.

Sunarto. (2020) Pengaruh penerapan Sistem E-Filling, Pemahaman Perpajakan dan Sanksi Perpajakan terhadap Kepatuhan wajib pajak. Journal of Islamic Accounting and Tax, 2020: 9-16.

Wijaya, S. (2019) Taxpayer Attitude on the Elimination of Tax Sanction and Taxation Awareness toward Taxpayer Compliance in Yogyakarta. Jurnal Manajemen Indonesia Vol.19 No.1, 2019: 71-79. 